\title{
Berat Karkas dan Lemak Abdominal Ayam Broiler yang diberi Tepung Jintan Hitam (Nigella sativa) dalam Ransum selama Musim Panas
}

\author{
S. Salam, A. Fatahilah, D. Sunarti, dan Isroli \\ Program Studi Magister Ilmu Ternak, Program Pascasarjana Fakultas Peternakan dan Pertanian, \\ Universitas Diponegoro \\ E-mail: syahfiisalam@gmail.com
}

\begin{abstract}
ABSTRAK
Penelitian ini bertujuan untuk mengetahui pengaruh penggunaan jintan hitam dan antibiotik terhadap berat karkas dan lemak abdominal ayam broiler selama musim panas. Penelitian dilaksanakan pada bulan September sampai Oktober 2012. Materi yang digunakan dalam penelitian ini adalah 100 ekor DOC ayam broiler unsex strain CP 707, serta ransum broiler fase starter dan finisher yang ditambahkan tepung jintan hitam. Bahan pakan penyusun yang digunakan antara lain terdiri dari jagung, bekatul, bungkil kedelai, minyak sawit, tepung ikan, kapur dan top mix. Komposisi nutrien dalam ransum mengandung $22,91 \%$ protein kasar dan $2.994 \mathrm{kkal} / \mathrm{kg}$ untuk fase starter and 20,01\% protein kasar dan $3.054 \mathrm{kkal} / \mathrm{kg}$ untuk fase finisher. Penelitian ini menggunakan rancangan acak lengkap dengan 5 perlakuan dan 4 ulangan, dan tiap ulangan terdiri atas 5 ekor ayam. Perlakuan yang diterapkan adalah T0 (Ransum basal); T1 (Ransum basal dan antibiotik oxytetracycline); T2 (Ransum yang ditambahkan jintan hitam 2\%); T3 (Ransum yang ditambahkan jintan hitam 4\%); T4 (Ransum yang ditambahkan jintan hitam 6\%). Penimbangan berat karkas dan lemak abdominal dilakukan pada umur 28 hari. Data yang diperoleh dianalisis ragam dengan uji $\mathrm{F}$, bila terdapat pengaruh perlakuan dilanjutkan dengan uji wilayah ganda Duncan. Hasil penelitian menunjukkan bahwa pemberian tepung jintan hitam (Nigella sativa) dan antibiotik dalam pakan sebagai feed additive tidak dapat meningkatkan persentase karkas maupun menurunkan kandungan lemak abdominal ayam broiler. Persentase pemberian jintan hitam 2-6\% dalam pakan memiliki kemampuan yang sama terhadap antibiotik terhadap bobot karkas dan persentase lemak abdominal ayam broiler selama musim panas.
\end{abstract}

Kata kunci: Jintan hitam, fisiologi darah, organ limfoid, ayam broiler

\section{Carcass Weight and Broiler Abdominal Fat Advised of Nigella sativa in the Ration during Summer Seasons}

\begin{abstract}
This study aimed to determine the effect of the use of black cumin and antibiotics on carcass weight and abdominal fat of broilers during summer seasons. The material in this study were used 100 individuals unsex one-day old broiler strain CP 707, and the ration of broiler were added black cumin powder (BCP). The ration consisted of yellow corn, rice brand, soybean meal,palm oil, fish meal, calsium and top mix. The diet was protein energy with $22.91 \%$ protein and 2,994 $\mathrm{kcal} / \mathrm{kg}$ for starter and $20,01 \%$ protein and $3.054 \mathrm{kcal} / \mathrm{kg}$ for finisher. Experiment was conducted as a completely randomized design with 5 treatments (control, antibiotic without BCP, $2 \%$ BCP, 4\%BCP and $6 \%$ $B C P)$. Carcas weight and abdominal fat was measured on at 28 day of age. The resulted data was analysed by analysis of variance (ANOVA) with $F$ test to know the effect of treatment, and when there were significant continous to Duncan multiple range test. The results showed that addition of black cumin (Nigella sativa) and antibiotics as a feed additive in ration cannot increase carcass weight and peesentase abdominal fat of broilers during summer seasons. level of black cumin 2-6\% in the feed has the same ability to antibiotics against carcass weight and percentage of abdominal fat of broilers.
\end{abstract}

Key words: Broiler, antibiotic, carcass weigth, abdominal fat 


\section{PENDAHULUAN}

Ayam broiler modern untuk saat ini memiliki kandungan lemak yang cukup tinggi namun dari hasil seleksi secara intensif ternyata menyebabkan peningkatan kandungan lemak dalam karkas hingga mencapai $18 \%$, sehingga masalah tersebut menjadi perhatian khusus bagi para konsumen dan produsen ternak. Lemak abdominal yang tinggi korelasi positif terhadap kandungan lemak karkas yang merupakan cerminan penumpukkan lemak yang berlebihan pada ayam broiler (Chambers et al, 1983). Penimbunan lemak abdominal pada ayam broiler dianggap sebagai hasil ikutan dan penghamburan energi ransum, juga menyebabkan menurunnya berat karkas yang dapat dikonsumsi (Griffiths et al. 1978).

Pemeliharaan ayam broiler di Indonesia pada umumnya dihadapakan dengan berbagai masalah antara lain seperti suhu lingkungan yang sangat tinggi pada musim kemarau. Cekaman panas akibat suhu lingkungan tinggi yang terus menerus akan mengakibatkan perubahan fisiologis seperti peningkatan hormon glukokortikoid yang dapat mengganggu perfomans pada ayam broiler (Sugito dan Delima, 2009). Cekaman panas akan membuat ayam broiler kurang bergerak sehingga menghasilkan timbunan lemak abdominal karena ayam menggunakan energi lebih banyak sebagai usaha untuk tetap nyaman dengan cara panting. Menurut Chwalibag dan Eggum (1989) menyatakan bahwa suhu lingkungan tinggi dapat meningkatkan kandungan lemak tubuh, sedangkan bobot karkas dan bagianbagian karkas yang dipelihara pada suhu sedang memiliki berat yang lebih besar dibandingkan dengan pemeliharaan pada suhu tinggi (Smith, 1993). Menurut Havenstein et al. (2003) menjelaskan bahwa kandungan lemak pada ayam pedaging pada umur 43 hari berkisar antara 10 sampai $15 \%$ dari total bobot karkas. Oleh karena itu maka perlu dicari teknologi alternatif yang dapat memperbaiki kualitas dan kuantitas daging disaat cekaman panas tinggi akibat suhu lingkungan sehingga dapat meningkatkan efisiensi pakan dan kualitas karkas untuk mengurangi kandungan lemak abdominal pada ayam broiler (Leclerq dan Witehead, 1988).

Penggunaan antibiotik sebagai obat antistress akibat cekaman panas dinilai kurang baik digunakan karena menimbulkan residu dan membahayakan konsumen. Penggunaan antibiotik dapat meningkatkan penyakit infeksi yang resistan terhadap antibiotik pada manusia (Murdiati, 1997; Saleha et al., 2009). Penggunaan antibiotika secara berlebihan dikhawatirkan akan mengganggu keseimbangan mikroorganisme dalam saluran pencernaan serta resistensi mikroorganisme terhadap antibiotik (An den bogaard dan Stobberingh, 2000). Tanaman herbal sering digunakan sebagai feed additive untuk menunjang produktivitas ternak unggas karena memiliki kemampuan untuk mengurangi dampak stress lingkungan dan tidak menimbulkan residu bagi tubuh ternak maupun manusia jika dikonsumsi secara berlebihan. Komponen bioaktif dalam tanaman herbal merupakan senyawa yang memiliki fungsi fisiologis spesifik dan mengurangi dampak stress akibat suhu lingkungan tinggi. Penambahan jintan hitam dengan dosis pemberian $2-40 \mathrm{~g} / \mathrm{kg}$ pakan mampu meningkatkan bobot badan dan menurunkan konversi pakan secara signifikan terhadap broiler kontrol (Guler et al., 2006; Durrani et al., 2007; Al-Beitawi dan El-Ghousein, 2008; Shewita dan Taha, 2011). Hasil penelitian berbeda dilaporkan oleh Abbas dan Ahmed (2010) dimana suplementasi jintan hitam pada level $1 \%$ dan $2 \%$ dari berat pakan ternyata tidak berpengaruh terhadap kontrol bahkan menghasilkan performa dan kualitas karkas yang menurun. Perbedaan hasil penelitian ini mungkin disebabkan karena faktor perbedaan dosis, jenis ayam dan usia ayam, oleh karena itu penelitian lebih lanjut dengan parameter menyeluruh perlu dilakukan untuk membuktikan khasiat jintan hitam. Oleh karena itu dengan pemberian jintan hitam sebagai feed additive dapat memperbaiki kualitas dan kuantitas daging disaat cekaman 
Tabel 1. Susunan Ransum Penelitian

\begin{tabular}{lcc}
\hline Komponen & $\begin{array}{c}\text { Starter } \\
\text { (usia 1 - 3 minggu) }\end{array}$ & $\begin{array}{c}\text { Grower } \\
\text { (usia 4 - 5 minggu) }\end{array}$ \\
\hline Jenis Bahan Pakan (\%) & 51 & 55 \\
Jagung & 15 & 17 \\
Bekatul & 20 & 13 \\
Bungkil kedelai & 11 & 11 \\
Tepung ikan & 2 & 3 \\
Minyak sawit & 0,5 & 0,5 \\
Kapur & 0,5 & 0,5 \\
Top Mix & & \\
Kandungan Nutrien & 2.994 & 3.054 \\
EM (kkal/kg) & 22,91 & 20,01 \\
PK (\%) & 5,89 & 7,04 \\
Lemak Kasar (\%) & 6,17 & 6,44 \\
Serat Kasar (\%) & 1,05 & 1,03 \\
Kalsium (Ca) (\%) & 2,23 & 2,45 \\
Fosfor (P) (\%) & 0,45 & 0,42 \\
Metionin $(\%)$ & 0,76 & 0,69 \\
Metionin + Sistin (\%) & 1,34 & 1,16 \\
Lisin & & \\
\hline
\end{tabular}

panas tinggi akibat suhu lingkungan. Pemberian jintan hitam dalam pakan diharapkan dapat meningkatkan persentase karkas dan menurunkan kandungan lemak abdominal ayam broiler pada musim panas.

\section{MATERI DAN METODE}

Materi yang digunakan dalam penelitian ini adalah day old chicken (DOC) ayam broiler "unsex" strain CP 707 sebanyak 100 ekor. Rancangan penelitian yang digunakan dalam penelitian ini adalah rancangan percobaan acak lengkap (RAL) dengan 5 perlakuan dan 4 ulangan, dan tiap ulangan terdiri atas 4 unit percobaan. Perlakuan yang diterapkan adalah T0 (Ransum basal); T1 (Ransum basal dan antibiotik oxytetracycline); T2 (Ransum yang ditambahkan jintan hitam 2\%); T3 (Ransum yang ditambahkan jintan hitam 4\%); T4 (Ransum yang ditambahkan jintan hitam 6\%). Susunan ransum dan kandungan nutrisinya terdapat pada Tabel 1.

\section{Persentase Bobot Karkas (\%)}

Persentase bobot karkas diperoleh dengan membandingkan bobot ayam tanpa bulu, darah, kepala, leher, kaki dan organ dalam (gram) dengan bobot hidup (gram) dikalikan $100 \%$.

\section{Persentase Bobot Lemak Abdomen}

Pengukuran bobot lemak abdomen dilakukan dengan cara menimbang lemak yang didapat dari lemak yang berada pada sekeliling gizzard dan lapisan yang enempel antara otot abdomen serta usus dan selanjutnya ditimbang. Persentase lemak abdomen diperoleh dengan membandingkan bobot lemak abdomen dengan bobot hidup dikalikan 100 (Witantra, 2011).

$$
\text { Lemak Abdomen }=\frac{\text { Bobot Lemak Abdomen }}{\text { Bobot Hidup }} \times 100 \%
$$

\section{Analisis Data}

Data yang diperoleh dianalisis ragam dengan uji $\mathrm{F}$ dan apabila terdapat pengaruh perlakuan yang nyata, maka dilanjutkan 
dengan uji wilayah ganda Duncan untuk mengetahui perbedaan antar perlakuan. Kriteria pengambilan keputusan pada taraf kepercayaan $95 \%$ atau $\alpha=0,05$ apabila $F$ hitung > F tabel maka $\mathrm{H}$ ditolak dan $\mathrm{H} 1$ diterima (Steel dan Torrie, 1994).

\section{HASIL DAN PEMBAHASAN}

\section{Pengaruh Jintan Hitam terhadap Bobot Karkas dan Persentase Karkas}

Hasil penelitian penggunaan jintan hitam dan antibiotik dalam ransum terhadap bobot karkas dan persentase karkas dapat dilihat pada Tabel 2. Berdasarkan hasil statistik, penggunaan jintan hitam dan antibiotik sebagai imbuhan pakan dalam ransum tidak berpengaruh nyata $(\mathrm{P}>0,05)$ terhadap persentase karkas ayam broiler maupun terhadap kontrol. Hal ini disebabkan karena bobot akhir yang tidak berbeda nyata akibat dari konsumsi ransum dan bobot potong yang juga tidak berbeda nyata. Menurut Haroen (2003) menyatakan bahwa bobot karkas sangat erat kaitannya dengan bobot potong dan pertambahan bobot badan. Rata-rata persentase karkas yang dihasilkan dalam penelitian (Tabel 2 dan Gambar 1) masih termasuk dalam kisaran normal. Persentase karkas bagian tubuh ayam broiler berkisar antara $65-75 \%$ dari bobot hidup dan persentase karkas dipengaruhi oleh bobot badan akhir dan bobot karkas (Jull, 1972).

Perlakuan penggunaan antibiotik menunjukkan hasil bobot karkas yang sama dengan dengan semua perlakuan level jintan hitam. Hal ini menunjukkan bahwa kemampuan antibiotik memiliki kemampuan yang sama dibandingkan dengan perlakuan jintan hitam hingga level $6 \%$ terhadap bobot karkas ayam broiler selama musim panas. Perlakuan antibiotik tidak berbeda dengan perlakuan kontrol karena ada pengaruh suhu lingkungan tinggi sehingga antibiotik (oxytetracycline) tidak dapat meningkatkan performans ayam broiler. Menurut Kalavathy et al. (2008) bahwa terjadi peningkatan secara signifikan terhadap efisiensi pakan sebelum dilakukan perlakuan cekaman panas, tetapi tidak terjadi peningkatan setelah perlakuan pemberian ransum antibiotik (oxytetracycline) maupun terhadap ransum kontrol selama perlakuan cekaman panas. Perbedaan respon pada antibiotik mungkin juga disebabkan karena jenis antibiotik dan strain ayam broiler yang digunakan. Menurut Zulkifli et al. (2000) menyatakan bahwa efisiensi pakan terbaik terdapat pada strain broiler Hubbard dan Shaver setelah perlakuan Lactobacillus culture dibandingkan dengan oxytetracycline maupun terhadap ransum kontrol.

Perlakuan setiap level jintan hitam menunjukkan hasil bobot karkas yang sama dibandingkan denga kontrol. Hasil yang sama dinyatakan oleh Abbas dan Ahmed (2010) dimana suplementasi jintan hitam pada level $1 \%$ dan $2 \%$ dalam pakan ternyata tidak berpengaruh terhadap kontrol bahkan menghasilkan performa dan kualitas karkas yang menurun. Hasil yang berbeda dinyatakan oleh Hermes et al. (2011) pemberian minyak jintan hitam, biji jintan hitam dan tepung jintan hitam dapat meningkatkan bobot hidup dan organ penceraan ayam broiler. Perbedaan hasil yang berbeda dari setiap perlakuan mungkin disebabkan karena penggunaan jenis jintan hitam yang diberikan berbeda.

Tabel 2. Rataan Bobot dan Persentase Karkas pada Masing-masing Perlakuan

\begin{tabular}{lccccc}
\hline \hline \multicolumn{1}{c}{ Parameter } & \multicolumn{5}{c}{ Perlakuan } \\
& T0 & T1 & T2 & T3 & T4 \\
\hline Bobot Karkas (g) & 626,50 & 668,25 & 632,50 & 663,50 & 645,50 \\
Persentase Karkas (\%) & 71,66 & 66,68 & 65,37 & 66,50 & 64,69 \\
\hline
\end{tabular}

Keterangan : Hasil analisis ragam terhadap parameter menunjukan tidak ada perbedaan yang nyata $(\mathrm{P}>0,05)$ 
Tabel 3. Rataan Bobot dan Persentase Lemak Abdominal (LA) pada masing-masing Perlakuan

\begin{tabular}{lccccc}
\hline \hline \multirow{2}{*}{ Parameter } & \multicolumn{5}{c}{ Perlakuan } \\
\cline { 2 - 5 } & $\mathrm{T} 0$ & $\mathrm{~T} 1$ & $\mathrm{~T} 2$ & $\mathrm{~T} 3$ & $\mathrm{~T} 4$ \\
\hline Bobot LA $(\mathrm{g})$ & 12,50 & 14,55 & 13,28 & 17,75 & 14,60 \\
Persentase LA $(\%)$ & 2,00 & 2,18 & 2,10 & 2,07 & 2,26 \\
\hline Keterangan : Hasil analisis ragam terhadap parameter menunjukan tidak ada perbedaan & yang nyata $(\mathrm{P}>0,05)$
\end{tabular}

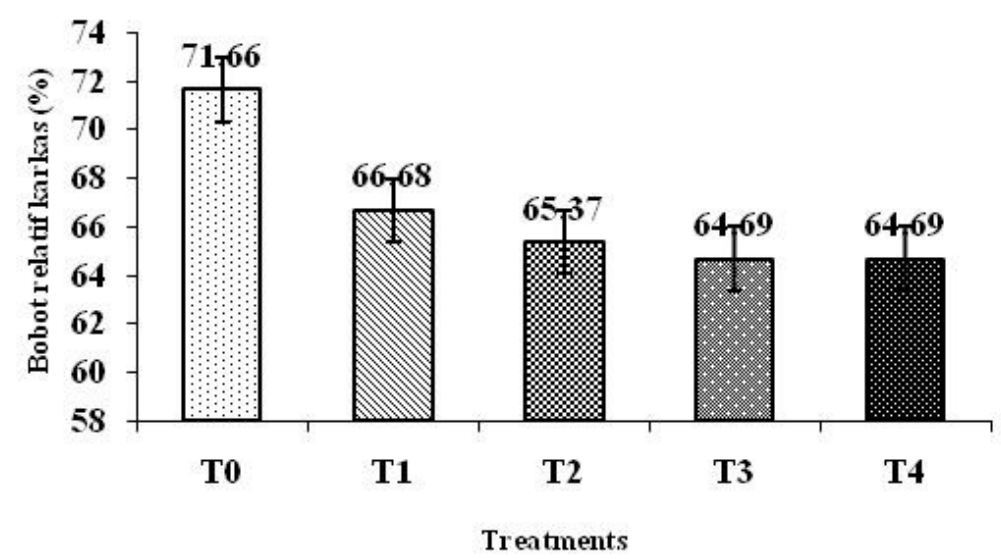

Gambar 1. Pengaruh jintan hitam dan antibiotik terhadap bobot relatif karkas (\%). (T0) = Ransum basal. $(\mathrm{T} 1)=$ Ransum basal dan antibiotik oxytetracycline. $(\mathrm{T} 2)=$ Ransum yang ditambahkan jintan hitam 2\%. (T3) = Ransum yang ditambahkan jintan hitam 4\%. (T4) Ransum yang ditambahkan jintan hitam $6 \%$.

\section{Pengaruh Jintan Hitam terhadap Bobot Lemak Abdominal dan Persentase Lemak Abdominal}

Hasil penelitian penggunaan jintan hitam dan antibiotik dalam ransum terhadap bobot karkas dan persentase karkas dapat dilihat pada Tabel 3 dan Gambar 2.

Berdasarkan hasil statistik, penggunaan jintan hitam dan antibiotik sebagai imbuhan pakan dalam ransum tidak berpengaruh nyata $(\mathrm{P}>0,05)$ terhadap persentase lemak abdominal ayam broiler maupun terhadap kontrol. Rata-rata persentase lemak abdominal yang dihasilkan dalam penelitian (Tabel 3) masih termasuk dalam kisaran normal yaitu sebesar 2,12\%. Menurut Becker et al (1979) menyatakan bahwa persentase lemak abdominal ayam broiler berkisar antara $0,73 \%$ sampai $3,78 \%$. Lemak abdominal mempunyai hubungan korelasi dengan total lemak karkas, semakin tinggi kandungan lemak abdominal maka semakin tinggi kandungan lemak karkas pada ayam broiler (Pfaff dan Austic, 1975; Leclerq dan Witehead, 1988).

Perlakuan antibiotik menunjukkan persentase lemak abdominal yang sama dengan perlakuan kontrol. Hasil yang sama juga dinyatakan oleh Bozkurt et al. (2008) menyatakan bahwa bobot lemak abdominal tidak berbeda nyata setelah pemberian antibiotik atau kombinasi antibiotik dengan manaan oligosaccharide (MOS) dibandingkan dengan kontol pada ayam broiler. Perlakuan penggunaan antibiotik menunjukkan hasil persentase lemak abdominal yang sama dengan dengan semua perlakuan level jintan hitam. Hal ini menunjukkan bahwa kemampuan antibiotik memiliki kemampuan yang sama dibandingkan dengan perlakuan jintan hitam terhadap persentase lemak abdominal. Perlakuan jintan hitam tidak dapat 


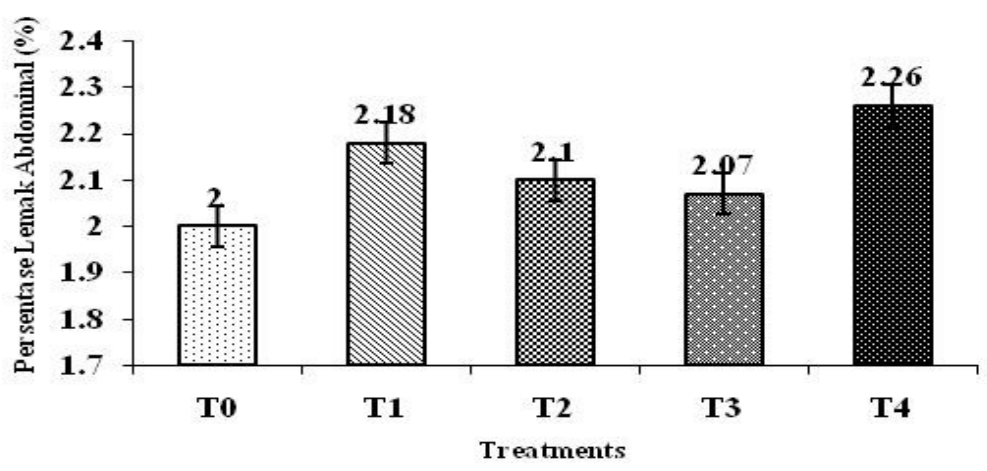

Gambar 2. Pengaruh jintan hitam dan antibiotik terhadap bobot relatif karkas (\%). (T0) = Ransum basal. $(\mathrm{T} 1)=$ Ransum basal dan antibiotik oxytetracycline . $(\mathrm{T} 2)=$ Ransum yang ditambahkan jintan hitam 2\%. (T3) = Ransum yang ditambahkan jintan hitam 4\%. (T4) Ransum yang ditambahkan jintan hitam 6\%.

mengurangi deposit lemak abdominal karena terjadi kandungan energi ransum yang sama sehingga konsumsi ransum tingkat penimbunan energi dalam tubuh dalam bentuk lemak tubuh sama antar perlakuan. Menurut Fontana et al. (1993) lemak abdomen akan meningkat pada ayam yang diberi ransum dengan protein rendah dan energi ransum yang tinggi. Energi yang berlebih akan disimpan dalam bentuk lemak dalam jaringan-jaringan. Salah satu bagian tubuh yang digunakan untuk menyimpan lemak oleh ayam adalah bagian sekitar perut (abdomen). Genotip, jenis kelamin, dan nutrisi dari ayam broiler merupakan beberapa faktor yang memengaruhi deposisi lemak tubuh (Tumova dan Teimouri, 2010). Menurut Ristic (2005) jumlah lemak abdominal ayam broiler strain Cobb500 lebih rendah $0,4 \%$ dibandingkan dengan strain Ross.

\section{SIMPULAN}

Hasil penelitian menunjukan bahwa pemberian tepung jintan hitam (Nigella sativa) dan antibiotik dalam pakan sebagai feed additive tidak meningkatkan persentase karkas dan menurunkan kandungan lemak abdominal ayam broiler. Persentase pemberian jintan hitam 2-6\% dalam pakan memiliki kemampuan yang sama terhadap antibiotik terhadap bobot karkas dan persentase lemak abdominal ayam broiler.

\section{DAFTAR PUSTAKA}

Abbas, T. E. E and M. E. Ahmed. 2010. Effect of supplementation of nigella sativa seeds to the performance and carcass quality. Int. J. Agr. Sci. 2 (2): 09-13.

An den Bogaard, A. E dan E. E. Stobberingh. 2000. Epidemiology of resistance to antibiotics. Int. J. Ant. Agents. 24: 327335.

Al-Beitawi, N. A and S.S. El-Ghousein. 2008. Effect of feeding different levels of nigella sativa seeds (black cumin) on performance, blood constituents and carcass characteristics of broiler chicks. Int. J. Poult. Sci. 7(7): 715-721.

Becker W. A, J.V. Spencer, L.W. Minishand and J.A. Werstate. 1979. Abdominal and carcas fat in five broiler strain. Poult. Sci. 60: 692-697.

Bozkurt, M., K. Küçükyilmaz, A.U. Çatli and M. Çinar. 2008. Growth performance and slaughter characteristics of broiler chickens fed with antibiotic, mannan oligosaccharide and dextran oligosaccharide supplemented diets. Int. J. Poult. Sci. 7(10): 969-977.

Chambers, J. R., A. Fortin and A. A. Grunder. 1983. Relationships between carcass fatness and feed efficiency and its component traits in broiler chickens. Poult. Sci. 62: 2201-2207.

Chawalibag, A and B. O. Eggum. 1989. Effect of temperature on performance, heat production, evaporative heat loss and body composition in chickens. Arch. Geflgelked. 53: 179-184. 
Durrani, F. R., N. Chand, K. Zaka,, A. Sultan, F. M. Khattak and Z. Durrani. 2007. Effect of different level of feed added black seed (Nigella sativa l.) on the performance of broiler chicks. Pakistan J. Biol. Sci. 10 (22): 4164-4167.

Fontana, E. A., D. Weaver Jr, D. M. Denbaow and B. A. Watkins. 1993. Early feed restricition of broiler : Effect on abdominal fat pad, liver, and gizzard weight, fat deposition and carcass composition. Poult. Sci. 72: 243 - 250.

Guler, T., B. Dalkilic, O. N. Ertas, M. Ciftci. 2006. The Effect of Dietary Black Cumin Seeds (Nigella Sativa L.) on the Performance of Broilers. Asian-Aust J. Anim. Sci. 19: 425-430.

Griffiths, L., S. Leeson and J. D. Summer. 1978. Studies on abdominal fat with four commercial strain of male broiler chicken. Poult. Sci. 52: 1198-1203.

Haroen, U. 2003. Respon Ayam Broiler yang Diberi Tepung Daun Sengon (Albizzia falcataria) dalam Ransum terhadap Pertumbuhan dan Hasil Karkas. J. Ilmiah Ilmu-ilmu Peternakan. 6 (1): 34-41.

Havenstein, G. B., P. R. Ferket and M. A. Qureshi. 2005. Growth, livability and feed conversion of 1957 versus 2001 broilers when fed representative 1957 and 2001 broiler diets. Poult. Sci. 82: 15001508.

Hermes, I. H., F.M. Attia, K.A. Ibrahim and S.S. EL-nesr. 2010. Physiological responses of broiler chickens to dietary different forms and levels of nigella sativa 1., during egyptian summer season. J. Agri. and Vet. Sci. 4(1): 17-33.

Jull, M. A. 1972. Poultry Husbandry. 2nd Ed. Tata McGraw Hill Book Publishing Co. Ltd., New Delhi.

Kalavathy, R., N. Abdullah, S. Jalaludin, C.M.V.L. Wong and Y.W. Ho. 2008. Effect of Lactobacillus cultures and oxytetracycline on the growth performance and serum lipids of chickens. Int. J. Poult. Sci. 7(4): 385-389.

Leclerq, B and C.C. Witehead. 1988. Leanness in Domestic Birds. The Institute Nasional de la Recherche Agronomique, London.

Murdiati, T. B. 1997. Pemakaian antibiotika dalam usaha peternakan. Wartazoa 6(1): 18-22.
Pfaff, F. E., JR and R. E. Austic. 1976. Influence of diet on development of the abdominal fat pad in the pullet. J. Nutr. 160: 443450.

Ristic, M. 2005. Influence of breed and weight class on the carcass value of broilers. In: X11th European Symp. Quality of Poultry Meat, Doorwerth, The Netherlands. Pp. 23-26.

Saleha, A. A., T. T. Myaing, K. K. Ganapathy, I. Zulkifli, R. Raha and K. Arifah. 2009. Possible effect of antibiotik-suplemented feed and enviroment on the occurrence of multiple antibiotik resistant escherichia coli in chickens. Int. J. Poult. Sci. 8(1): 28-31.

Shewita, R. S and A. E. Taha. 2011. Effect of dietary supplementation of different levels of black seed (Nigella Sativa L.) on growth performance, immunological, hematological and carcass parameters of broiler chicks. World Academy of Science, Engineering and Technology. 77: 788-794.

Sugito dan M. Delima. 2009. Dampak cekaman panas terhadap pertambahan bobot badan, rasio heterofil:limfosit dan suhu tubuh ayam broiler. J. Ked. Hewan 3(1): 216226.

Smith, M. O. 1993. Parts yield of broiler reared under cycling higt temperatures. Poult. Sci. 72: 1146-1150.

Steel, G.D. dan J.H, Torrie. 1994. Prinsip dan prosedur statistika. Sumantri penerjemah; jakarta: penerbit PT. Gramedia Pustaka Utama. Terjemahan dari: Principles and Prosedur Of Statistic.

Tumova, E dan A. Teimouri. 2010. Fat deposition in the broiler chicken: A review. Scientia Agriculturae Bohemica. 41(2): 121-128.

Witantra. 2011. Pengaruh Pemberian Lisin dan Metionin Terhadap Persentase Karkas dan Lemak Abdominal pada AyamPedaging Asal Induk Bibit Mudadan Induk Bibit Tua. Artikel Ilmiah. Universitas Airlangga. Surabaya.

Zulkifli, I., N. Abdullah, N. Mohd. Azrin and Y.W. Ho. 2000. Growth performance and immune response of two commercial broiler strains fed diets containing Lactobacillus cultures and oxytetracycline under heat stress conditions. Br. Poult. Sci. 41, 593-597. 